\title{
Erratum to: Effects of Chlorella vulgaris and Arthrospira platensis addition on viability of probiotic bacteria in yogurt and its biochemical properties
}

\author{
Hannane Beheshtipour • Amir Mohammad Mortazavian • \\ Parivash Haratian · Kianoosh Khosravi Darani
}

Published online: 19 October 2012

(c) Springer-Verlag Berlin Heidelberg 2012

\section{Erratum to: Eur Food Res Technol DOI 10.1007/s00217-012-1798-4}

In the original version of the article, references 17, 18, 19, 25, 28 and 31 were incorrectly published. The corrected references are given below:

17. Gyenis B, Szigeti J, Molnár N, Varga L (2005) Use of dried microalgal biomasses to stimulate acid production and growth of Lactobacillus plantarum and Enterococcus faecium in milk. Acta Agraria Kaposváriensis 9(2):53-59

18. Molnár N, Gyenis B, Varga L (2005) Influence of a powdered Spirulina platensis biomass on acid production of lactococci in milk. Milchwissenschaft 60:380-382

19. Varga L, Szigeti J, Kovács R, Földes T, Buti, S (2002) Influence of a Spirulina platensis biomass on the microflora of fermented ABT milks during storage. J Dairy Sci 85:1031-1038

The online version of the original article can be found under doi:10.1007/s00217-012-1798-4.

H. Beheshtipour · A. M. Mortazavian $(\varangle) \cdot$ P. Haratian Department of Food Science and Technology,

National Nutrition and Food Technology Research Institute,

Faculty of Nutrition Sciences, Food Science and Technology,

Shahid Beheshti University of Medical Sciences,

P.O. Box 19395-4741, Tehran, Iran

e-mail: mortazvn@sbmu.ac.ir

\section{K. K. Darani}

Department of Food Technology Research,

National Nutrition and Food Technology Research Institute,

Faculty of Nutrition Sciences, Food Science and Technology,

Shahid Beheshti University of Medical Sciences,

P. O. Box 19395-4741, Tehran, Iran
25. Varga L, Szigeti J (1998) Microbial changes in natural and algal yoghurts during storage. Acta Aliment Hung 27:127-135

28. Varga L, Szigeti J, Ördög V (1999) Effect of a Spirulina platensis biomass and that of its active components on single strains of dairy starter cultures. Milchwissenschaft 54:187-190

31. Ásványi-Molnár N, Sipos-Kozma Zs, Tóth Á, Ásványi B, Varga L (2009) Development of a functional dairy food enriched with Spirulina (Arthrospira platensis). Tejgazdaság 69(2):15-22 